\title{
A SEPARAÇÃO DE PODERES E A FUNÇÃO JUDICIÁRIA EM JOHN LOCKE, MONTESQUIEU E HAMILTON, MADISON E JAY
}

\author{
THE SEPARATION OF POWERS AND THE JUDICIAL FUNCTIONS IN JOHN \\ LOCKE, MONTESQUIEU E HAMILTON, MADISON E JAY
}

${ }^{1}$ Maurício Pires Guedes

\section{RESUMO}

Surgem atualmente no cenário político mundial diversos movimentos que buscam conformar, no plano da teoria do direito e do Estado, as bases de um novo paradigma filosófico relacionado a novas técnicas de hermenêutica constitucional. Este movimento é fruto de um longo desenvolvimento histórico e político cujas bases imediatas estão diretamente fincadas ao período de consolidação do Estado moderno. O objeto que se pretende tratar no presente artigo científico, a separação de poderes a partir da função do poder judiciário em diferentes matrizes culturais neste período, reflete bem esta condição. A análise das visões do inglês John Locke, do francês Montesquieu e dos norte-americanos Hamilton, Madison e Jay demonstrará a diversidade de acepções acerca da função judiciária e as respectivas influências delas decorrentes. Serão estes traços que se pretenderá apontar no presente artigo, buscando-se, na historicidade, o reconhecimento fundamental da própria experiência do direito, de modo a permitir, ao final, uma compreensão mais adequada da realidade institucional que hoje vivemos.

Palavras-chave: Pensamento político, Separação de poderes, Teorias do estado

\begin{abstract}
Currently there are emerging on the world political scene several movements that search for the foundation of a new philosophical paradigm related to new techniques of constitutional hermeneutics. This movement is the result of a long historical and political development whose immediate bases are directly attached to the consolidation of the modern state. This paper pretend to study the separation of powers, of diverse cultural matrices, from the judiciary function view, pretending to show these influences. From the perspective on history and law experience, these are the parameters we pretend to study, trying, at the end, an adequate understanding of institutional reality in which we live today.
\end{abstract}

Keywords: Political thought, Separation of powers, Theory of the stat

\footnotetext{
${ }^{1}$ Possui Mestrado em Direito pela Universidade Gama Filho, UGF - RJ, (Brasil). É professor da graduação e convidado da pós-graduação da Universidade Católica de Petrópolis - UCP - RJ, (Brasil).
} 


\section{INTRODUÇÃO:}

A análise comparativa dos principais sistemas jurídicos ocidentais aponta menos para uma proximidade ontológica que para uma diversidade de estruturas e de aspectos funcionais, demonstrando a dissensão de suas matrizes histórico-culturais.

E, por outro lado, o constitucionalismo contemporâneo, influenciado pela recíproca interação destes sistemas busca conformar, no plano da teoria do direito e do Estado, as bases de um novo paradigma juspolítico-filosófico que surge no cenário jurídico mundial após a segunda grande guerra.

A partir dos prefixos "neo" e "pós" agregados ao positivismo e ao constitucionalismo, como marca da superação das bases do regime anterior, estas diversas concepções do direito buscam a compreensão de que o formalismo que imperou no pensamento jurídico a partir do século XVIII deve ser substituído por considerações superiores de natureza moral e axiológica, de modo que, relacionadas a novas técnicas de hermenêutica, implicariam em verdadeira "mutação da cultura jurídica"² contemporânea.

Imbricado a este novo movimento paradigmático decorre a proeminência política do Poder Judiciário sobre os demais poderes, na medida em que, de fato, a ele é delegado um papel fundamental para o regular funcionamento deste organismo.

Ao lado dos métodos tradicionais de interpretação da norma surgem novas técnicas de hermenêutica que remodelam o pensamento da teoria do direito, notadamente o princípio da separação de poderes, fornecendo ao magistrado a liberdade necessária para decidir a causa que lhe é apresentada a partir de valores que extrapolam a mera aplicação formal da norma ao caso concreto.

O objeto que se pretende tratar no presente artigo científico, a função do poder judiciário em diferentes matrizes culturais no período histórico que antecede o surgimento do Estado moderno, reflete bem esta condição.

A análise das visões do inglês John Locke, do francês Montesquieu e dos norteamericanos Hamilton, Madison e Jay demonstrará a diversidade de acepções acerca da função judiciária e as respectivas influências delas decorrentes. Embora tal distinção, no presente caso, apresente relativo alcance, já que os rumos da história demonstram hoje a infiltração e contaminação entre tais acepções $^{3}$, principalmente se considerarmos os diferentes períodos em que foram

\footnotetext{
${ }^{2}$ A expressão é de SARMENTO (2010, p.239).

${ }^{3}$ Nesse sentido a expressa referência à Constituição Americana como tendo recebido atenção da Assembleia Nacional Francesa, conforme esclarece DUGUIT (1996, p. 18-21).
} 
produzidos, certo é que modelos estatais delas decorrentes apresentaram relevantes traços próprios e característicos que auxiliam, em nossa visão, o estudioso preocupado em compreender as bases políticas do mundo contemporâneo.

Serão estes traços que se pretenderá apontar no presente artigo, buscando-se, na historicidade, o reconhecimento fundamental da própria experiência do direito, de modo a permitir, ao final, uma compreensão mais adequada da realidade institucional que hoje vivemos.

Quanto a necessidade da apreensão dos elementos históricos para a melhor compreensão do período subsequentes valemo-nos das lições de SALDANHA que, ao destacar a relevância do fenômeno político a partir de uma abordagem histórica dos fatos, nos aponta elementos fundamentais, ao nosso ver, para o estudo mais completo da teoria do direito:

\begin{abstract}
Cabe, destarte, a uma teoria do direito que se disponha a ser fundamental, reconhecer e recolher, na própria experiência do direito (incluindo nesta ou relacionando com esta as formas do conhecimento jurídico culturalmente respectivas), sua dimensão histórica. Vale dizer: reconhecer a relativa variabilidade das formas, e sua relativa invariabilidade, ambos os casos compreensíveis historicamente, e não apenas logicamente. Também a variabilidade e a invariabilidade relativas dos valores se situa numa compreensão histórica. (...) Historicidade de valores não significa aqui propriamente negação da índole racional da idéia de valor, nem significa desconhecer que um valor se toma quase sempre em perspectiva intemporal. Mas é que as valorações são sempre atos situados em circunstâncias, e são elas que "preenchem" as formas, ou que as pedem, ou fabricam; de modo que a intemporalidade está no valor como numa idéia, mas não em sua presença ou atuação nas relações concretas dos homens. (1987, p. 26)
\end{abstract}

Nestes termos, iniciaremos nossa análise pelo "Segundo tratado sobre o governo" de John Locke, e sua definição para as funções a serem exercidas pelos diferentes poderes políticos, especialmente a legislativa e executiva.

Posteriormente passaremos a analisar a clássica tripartição de Montesquieu em seu "O Espírito das leis”, o que de certa forma já aproxima este estudo da realidade contemporânea dentro do pensamento jurídico e político ocidental.

E, por fim, trataremos da visão de Hamilton, Madison e Jay em "O federalista", e a separação de poderes enquanto instrumento de defesa da constituição norte-americana, o que, ao nosso ver, constitui a efetiva base para o direito constitucional contemporâneo.

\title{
2 . DA DIVISÃO BIPARTIDA DE FUNÇÕES DE JOHN LOCKE:
}


Em 1632, quarenta e quatro anos depois de Hobbes, nasce em Bristol, na Inglaterra, John Locke, no turbulento período de restauração dos Stuarts que somente se encerraria em 1660. Defensor do partido whig, e vencedor na revolução de 1688, Locke se coloca a serviço do partido com o objetivo de acalmar a inquietação e apaziguar as tensões de seus compatriotas.

Diante daqueles que viam a expulsão do Stuart Jaime II como violação ao sagrado soberano legítimo, poder este que se alicerçava na ideia de origem divina, "representante" que era de Deus na terra, tem esta tese em Locke um dos seus principais contendores, sendo manifesto este posicionamento quando defende a existência de direitos naturais do indivíduo já no estado de natureza, na tentativa de desmistificar e deslegitimar o estado absoluto até então existente.

Curioso relevar, nesse giro, que a justificativa para a inserção do homem no novo contexto social decorre da necessidade de se evitar alguns inconvenientes que poderiam advir do estado da natureza, aproveitando-se Locke deste momento para fixar diversos mecanismos e institutos anti-absolutistas na tentativa de evitar uma futura e eventual retomada do poder pelo regime anterior.

Este o sentido da leitura de CHEVALLIER, em especial do seguinte trecho:

\begin{abstract}
No Estado de natureza, cada um é juiz em causa própria; cada um, igual ao outro, é de certo modo rei; ele pode achar-se tentado a observar com pouco exatidão a equidade, a ser parcial em seu proveito e no dos amigos, por interesse, amor-próprio e fraqueza; pode-se achar-se tentado a punir por paixão e vingança: quantas ameaças graves à conservação da liberdade, da igualdade natural, ao gozo tranquilo da propriedade! Em suma, nesse estado natural, à primeira vista idílico, faltam: leis estabelecidas, conhecidas, recebidas e aprovadas por meio de comum consentimento; juízes reconhecidos, imparciais, criados para terminar com todas as diferenças de acordo com as lei estabelecidas; enfim, um poder coercitivo, capaz de assegurar a execução dos juízos proferidos. Ora, tudo isso encontra-se no estado de sociedade, sendo precisamente o que caracteriza tal estado. E foi para se beneficiarem de tais aperfeiçoamentos que os homens mudaram. (1999, p. 109-110)
\end{abstract}

Nesse contexto, nessa engenhosa retórica trazida para justificar a falta de legitimidade do poder absolutista derrotado, surge a distinção e separação de poderes na visão de Locke, como decorrente do pacto dos cidadãos firmados nesse novo estado social.

A divisão apresentada por Locke já demonstra sua preocupação em evitar o abuso do poder que o assenhoramento de tais funções nas mãos de uma só pessoa ou um só grupo poderia levar, embora de fato, não reste dúvida ter o referido autor propugnado uma maior relevância na atuação do função legislativa.

De fato, partindo dos poderes do homem no estado da natureza, Locke nos apresenta duas funções soberanas internas nessa sociedade política a ser instaurado: a legislativa, que teria a tarefa de definir o modo com que se deverá utilizar a força da comunidade para a preservação dela própria e de seus membros; e a executiva, que teria o encargo de assegurar internamente a execução 
das leis positivas.Ao lado deste dois poderes incluía Locke o poder federativo, cuja atribuição passaria notadamente pela gestão das relações exteriores com outras sociedades politicamente organizadas, em especial a questão da decretação da guerra ou da celebração da paz e o estabelecimento de acordos ou alianças.

Necessário nesse ponto destacar que embora relevante não é possível incluir Locke como efetivo expoente da tríplice separação de poderes que se consolidaria com a formação do Estado moderno, faltando-lhe, de fato, um maior desenvolvimento que somente seria alcançado por Montesquieu posteriormente, conforme bem esclarece FARIAS NETO (2011):

Locke explanou sobre a forma de governo civil que deve ser escolhido no contexto do contrato social determinante do estado civil estabelecido pelo consentimento unânime dos indivíduos, visando aliar o interesse comum aos interesses individuais. Na escolha do governo, ao invés da unanimidade do contrato originário, assomaria o princípio da maioria, em que a posição majoritária resultaria prevalecente, embora concomitantemente ao respeito pelos direito da minoria. Locke propugnou o fim da concentração de poder no monarca, de modo que o poder legislativo, escolhido pela maioria, teria superioridade sobre os demais poderes de Estado, ficando constituído como o poder supremo. O denominado poder federativo ficaria encarregado de gerir as relações exteriores, com outras sociedades politicamente organizadas, abrangendo a deliberação sobre guerra, paz, alianças e tratados. Ao poder legislativo, ficaria subordinado o poder executivo, confiado ao monarca, além do poder federativo. O poder executivo e o poder federativo poderiam, inclusive, ser exercidos pelo mesmo governante. A abordagem de Locke preceituou a existência de uma clara separação do poder legislativo em relação aos poderes executivo e federativo. Ao concentrar o poder executivo e o poder federativo, contudo, Locke não delineou a tripartição completa do poder, que ficou mais bem desenvolvida por Montesquieu (1689-1755), posteriormente, no século XVIII. (2011, p, 253)

De fato não há, dentro do quadro delineado por Locke, expressa referência a função jurisdicional a ser exercida independentemente dos demais poderes tal qual hoje nós a conhecemos, o que não significa, evidentemente, que não houvessem responsáveis por determinar, em lides concretas, a aplicação do direito da forma adequada

De acordo com este autor, a função executiva deveria englobar a função de julgar casos em que houvessem partes litigando, na medida em que a administração e a execução das leis incluía sua aplicação particular da norma no caso concreto. Significa dizer, em outras palavras, que cabia ao executivo a aplicação das leis na medida em que ínsito a finalidade deste órgão encontrava-se a necessidade de preservação da paz nas relações sociais.

Interessante observar, nesse passo, a preponderância da função legislativa sobre a executiva, tendo Locke explicitamente qualificado a produção da norma como sendo o poder supremo da comunidade. Nesse sentido a seguinte passagem encontrada no "Segundo tratado sobre governo o civil":

o poder supremo da comunidade, mas sagrado e intocável nas mãos a que a comunidade o confiou; nem pode um edito, seja de quem for, concebido de 
qualquer modo ou apoiado por qualquer poder, ter a força e a validade de lei se não tiver sanção do legislativo eleito pela comunidade. (2010, p. 90)

Relevante destacar, nesse sentido, que embora aparentemente inferior e submissa, a função executiva desempenhava, à luz de um critério de relevância social, função de igual repercussão ao do legislativo, o que possibilitaria, como consequência, o exercício do famoso direito de resistência e revolta por parte dos cidadãos, considerado por Locke direito natural e, por isso mesmo, inerente à natureza humana.

E mais: defendia Locke que ambos poderes recebiam dos governados o mesmo consentimento daquele suposto poder supremo e superior, de modo que tanto um, como outro, estavam submissos a soberania e a confiança do povo. Era o próprio povo, em última instância, quem tinha o poder de confiar a administração de suas vidas a quem lhe aprouvesse.

Dessa forma, e diante desse quadro, fica evidente que a divisão trazida por Locke das funções entre poder executivo e legislativo, excluído aqui o federativo pelas razões acima expostas - tinha por finalidade, em última instância, resguardar a soberania do povo da concentração de poderes em uma única pessoa ou em único órgão, o que permitiria, em sua visão, um maior equilíbrio no desenvolvimento das relações políticas e sociais. Nesse tema esclarece CHEVALLIER:

\footnotetext{
"embora Locke evite elaborar aqui uma construção rigorosa, o povo conserva sempre uma soberania potencial, em reserva: é ele, e não o legislativo, o detentor do verdadeiro poder soberano. (...) Quem julgará, entre o legislativo e o executivo, se este último fez bom ou mau uso da prerrogativa? Quem julgará, entre o legislativo e o povo, se o primeiro conspira para escravizar o segundo? Quem julgará, quem sancionará a fidelidade dos depositários (trustees) do poder, a eles confiado para o bem público? O povo, a título de depositante, "deve julgar a tal respeito".” (1999, p.109-110)
}

Interessante observar, conforme visto acima, que a maneira como Locke desenvolve essa ideia contrastará com aquela empregada por Montesquieu em sua obra, embora o desenvolvimento da função executiva de Locke em duas realidades distintas - poder administrativo e poder judiciário - acaba exatamente por caracterizar a tripartição apresentada e defendida pelo autor francês.

Diante de tal especificidade, e para uma melhor compreensão sobre este tema, passemos a analisar tal questão na ótica de Montesquieu, tendo como referência o seu clássico trabalho "O Espírito das leis". 


\title{
3. DA DIVISÃO TRIPARTIDA DE FUNÇÕES DE MONTESQUIEU:
}

A preocupação de usurpação do poder apresentada por Locke ecoa significativamente em Charles-Louis de Secondat, ou Barão de Montesquieu, pensador político francês do período iluminista, tendo merecido deste uma teorização muito mais completa e elaborada. De fato, é a liberdade o ponto de partida para a divisão de Montesquieu, como forma de evitar a preponderância de um poder sobre os demais. Não a liberdade do povo em que cada um pode fazer o que se quer. Na visão de Montesquieu, é a liberdade política, baseada nas leis - nos moldes da constituição da Inglaterra - em que só se pode fazer aquilo que as leis permitem.

Nesse passo defende MONTESQUIEU em clássica passagem para a Teoria de

Direito:

\begin{abstract}
A liberdade política, em um cidadão, é esta tranqüilidade de espírito que provém da opinião que cada um tem sobre sua segurança; e para que se tenha esta liberdade é preciso que o governo seja tal que um cidadão não possa temer outro cidadão. (2005, p. 168).
\end{abstract}

Nesse momento é que surge, por um lado, a "divisão vertical" ${ }^{3}$, visando resguardar, na célebre frase de Montesquieu, que "para que não se possa abusar do poder, é preciso que, pela disposição das coisas, o poder limite o poder" (2005, p. 166).

Este é o germe de sua separação de poderes, já que na visão de Montesquieu mesmo nos estados moderados garantidores da liberdade política, esta só existe efetivamente quando não há o abuso de quem possui o poder, experiência que o próprio apresenta como "eterna" no sentido de que todo o homem é levado a dele abusar.

Exsurge, nesse momento, a clássica divisão de funções entre os órgãos executivo, legislativo e judiciário, a partir da própria argumentação de que também a liberdade, à luz de sua teoria, precisaria ser limitada de modo a evitar a concentração de poderes nas mãos de uma única pessoa. "Quem diria!" afirma Montesquieu, "até a virtude precisa de limites” (2005, p.166).

\footnotetext{
${ }^{3}$ As expressões “divisão vertical” e "divisão horizontal” foram cunhadas por BOBBIO (1997. p. 136)
} 
Pela eloquência da argumentação, transcrevemos o seguinte trecho sobre este tema, que é fulcral para a compreensão daquilo que marcaria o pensamento político e jurídico do mundo ocidental contemporâneo:

\begin{abstract}
Quando, na mesma pessoa ou no mesmo corpo de magistratura, o poder legislativo está reunido ao poder executivo, não existe liberdade; porque se pode temer que o mesmo monarca ou o mesmo senado crie leis tirânicas para executá-las tiranicamente. Tampouco existe liberdade se o poder de julgar não for separado do poder legislativo e do executivo. Se estivesse unido ao poder legislativo, o poder sobre a vida e a liberdade dos cidadãos seria arbitrário, pois o juiz seria legislador. Se estivesse unido ao poder executivo, o juiz poderia ter a força de um opressor. Tudo estaria perdido se o mesmo homem, ou o mesmo corpo dos principais ou dos nobres, ou do povo exercesse os três poderes: o de fazer as leis, o de executar as resoluções públicas e o de julgar os crimes ou as querelas entre os particulares. (2005, p. 168).
\end{abstract}

Por outro, a "divisão horizontal" de poder defendida por Montesquieu, consubstanciada no clássico conceito de governo misto de Políbio em que as três forças concretas da sociedade ${ }^{4}$ - o povo, o monarca e a nobreza - estão combinados como forma de harmonizar as tensões sociais, em especial diante do efeito moderador deste último. ${ }^{5}$

Interessante observar, nesse passo, que embora a teoria da separação dos poderes tenha tido maior projeção, tanto que as primeiras constituições escritas, a norte-americana de 1789 e a francesa de 1791 nela se basearam, foi a "divisão horizontal” a grande proposta apresentada por Montesquieu em sua obra.

Isso porque, e esta questão nos interessa em especial no presente estudo, Montesquieu via na função jurisdicional um poder invisível e nulo: "não se têm continuamente juízes sob os olhos; e teme-se a magistratura, e não os magistrados.” (2005, p. 169).

Dentro desse quadro é que surge a expressão "bouche de la loi"6 (boca da lei)imputada aos magistrados, no sentido de que os juízes devem apenas aplicar da forma mais mecânica possível as leis editadas pelo Legislativo, como forma de democraticamente garantir e assegurar os direitos do cidadão em face dos excessos do Estado.

\footnotetext{
${ }^{4}$ E mais uma vez fica evidente a referência da divisão de poderes inglesa, cuja exteriorização, a partir da revolução de 1688, assumiria tal fisionomia.

5 Nos moldes ingleses: o povo, na "câmara dos comuns", por eleição; os nobres na "câmara dos lordes", por

hereditariedade; e o monarca, na chefia do poder executivo.

6 Expressão cunhada por Montesquieu, no livro “O espírito das leis”
} 
Sobre esta atividade meramente mecânica esclarece Luiz Guilherme Marinoni (2009,p. 29-30)

De acordo com Montesquieu, o "poder de julgar" deveria ser exercido por meio de uma atividade puramente intelectual, não produtiva de "direitos novos". Essa atividade não seria limitada apenas pela legislação, mas também pela atividade executiva, que teria também o poder de executar materialmente as decisões que constituem o "poder de julgar". Nesse sentido, o poder dos juízes ficaria limitado a afirmar o que já havia sido dito pelo Legislativo, devendo o julgamento ser apenas "um texto exato da lei". Por isso, Montesquieu acabou concluindo que o "poder de julgar" era, de qualquer modo, um "poder nulo" (en quelque façon, nulle). Assim, conferiu-se o poder de criar o direito apenas ao Legislativo. A prestação judicial deveria se restringir à mera declaração da lei, deixando-se ao executivo a tarefa de executar as decisões judiciais. Para que se pudesse limitar o poder do juiz à declaração da lei, a legislação deveria ser clara e capaz de dar regulação a todas as situações conflitivas. Os Códigos deveriam ser claros, coerentes e completos. O medo do arbítrio judicial, derivado da experiência do ancien régime, não apenas exigia a separação entre o poder de criar o direito e o poder de julgar, como também orientava a arquitetura legislativa desejada. Além disto, o racionalismo exacerbado, típico da época, fazia acreditar que a tarefa judicial poderia ser a de apenas identificar a norma aplicável para a solução do litígio.

Esta concepção dos magistrados decorria da neutra posição na qual Montesquieu inseria a função jurisdicional, em contraposição aquela ativa do regime anterior em que, em razão da ausência de limites para a sua atuação, se confundia em muitas vezes com a própria função administrativa.

Por outro lado, elemento estrutural da sociedade política para Montesquieu passava pelo reconhecimento de que era a função legislativa, por suas duas casas, e o executivo os efetivos órgãos que exerciam plenamente o poder. Nesse sentido afirma MONTESQUIEU:

Eis então a constituição fundamental do governo de que falamos. Sendo o corpo legislativo composto de duas partes, uma prende a outra com sua mútua faculdade de impedir. Ambas estarão presas ao poder executivo, que estará ele mesmo preso ao legislativo. (...) Estes três poderes deveriam formar um repouso ou uma inação. Mas, como, pelo movimento necessário das coisas, eles são obrigados a avançar, serão obrigados a avançar concertadamente." (2005, p.176)

Fica evidente que mais do que a "equivalência" tão difundida na teoria da separação dos poderes, a preocupação de Montesquieu era propiciar a existência de instâncias independentes que assegurassem que não houvesse o abuso por parte de quaisquer deles. $\mathrm{E}$ tal papel, na visão de Montesquieu, seria exercido na interação entre as funções legislativas e executiva. 
Em igual sentido apresentamos a visão de ALBUQUERQUE:

\begin{abstract}
“(...) Montesquieu mostra claramente que há uma imbricação de funções e uma interdependência entre o executivo, o legislativo e o judiciário. A separação de poderes da teoria de Montesquieu teria, portanto, outra significação. Trata-se, dentro dessa ordem de idéias, de assegurar a existência de um poder que seja capaz de contrariar outro poder. Isto é, trata-se de encontrar uma instâncias independente capaz de moderar o poder do rei (executivo). É um problema político, de correlação de forças, e não um problema jurídico-administrativo, de organização de funções. Para que haja moderação é preciso que a instância moderadora (isto é, a instituição que proporcionará os famosos freios e contrapesos da teoria liberal da separação dos poderes) encontre sua força política em outra base social. Montesquieu considera a existência de dois poderes - ou de duas fontes de poder político, mas precisamente: o rei, cuja potência provém da nobreza, e o povo. É preciso que a classe nobre, de um lado, e a classe popular, de outro lado (na época "o povo" designa a burguesia", tenham poderes independentes e capazes de se contrapor. Em outras palavras, a estabilidade do regime ideal está em que a correlação entre as forças reais da sociedade possa se expressar também nas instituições políticas. Isto é, seria necessário que o funcionamento das instituições permitisse que o poder das forças sociais contrariasse e, portanto, moderasse o poder dos demais. (2006, p. 119-120)
\end{abstract}

Nesse passo, conforme visto acima, de acordo com Montesquieu o poder de julgar deveria ser exercido por meio de uma atividade puramente intelectual, não limitada apenas pela legislação, mas também pela função executiva que teria também o poder de fazer cumprir materialmente tais decisões.Nesse sentido, conferiu-se o poder de criar o direito apenas ao legislativo, ficando o poder dos juízes limitado à mera declaração da norma ao caso concreto. $\mathrm{O}$ medo do arbítrio judicial não apenas exigia tal separação na visão de Montesquieu, como também orientou, inequivocamente ao nosso ver, a opção legislativa de buscar, a partir da codificação, disciplinar todas as situações conflitivas que pudessem surgir no seio social.

Talvez não por outro motivo a preocupação de usurpação do poder apresentada por Montesquieu tenha ecoado significativamente nos revolucionários franceses que tomaram o poder em $1789^{7}$.

\footnotetext{
${ }^{7}$ Nesse sentido o discurso de Jean-Paul Marat à Assembléia Geral Francesa em agosto de 1789, apresentado textualmente por FAURÉ (1995, p. 276, tradução livre): “Montesquieu? Sim, Montesquieu, o maior homem que produziu o século e que ilustrou a França. Não se falará nem de seu gênio nem de suas virtudes: quem pode ignorá-las? Mas seu amor pela humanidade do qual sempre foi seu vingador; seu ódio contra o despotismo, ao qual buscou sempre lutar; seu respeito pela lei, seu zelo pelo bem-estar público, a sua devoção ao seu país, mereciam ser melhores conhecidos. Mentes superficiais e frívolas o criticam por ter favorecido a aristocracia. Talvez admirado um pouco além da conta por seu espírito de luta que mostrou durante muito tempo à nobreza da cavalaria: mas que homem no mundo poderia apreciar melhor o que há de vulgar nos nobres, que homem no mundo se sentiu mais diminuído pelos tribunais? Talvez nos faça falta um exagerado prejuízo que envolve os injustos e ingratos? Quão obrigados não estamos com ele? Seria o primeiro entre nós que desarmaria a superstição, arrancaria o punhal do fanatismo, reivindicando os direitos do homem contra a tirania. É! E em que momento. Em um tempo no qual ninguém na França se atreveu a falar contra um ministro, em uma época em que os franceses eram escravos por princípio."
} 
Nesse sentido, necessário observar que foi exatamente esta conformação dada à função jurisdicional, recém consolidada nas mãos do Estado, a mola-mestra para o desenvolvimento da Escola da Exegese na França a partir da codificação realizada por Napoleão em 1804, em que será submetido, de fato, o poder dos juízes à mera declaração da norma ao caso concreto.

Replicada em sua gênese pelos adeptos da doutrina da Escola da Exegese, fica evidente a restrita concepção deferida à função de julgar neste período a partir da análise do seguinte trecho de Montesquieu:

\begin{abstract}
Mas, se os tribunais não devem ser fixos, os julgamentos devem sê-lo a tal ponto que nunca sejam mais do que um texto preciso da lei. Se fossem uma opinião particular do juiz, viveríamos em sociedade sem saber precisamente os compromissos que ali assumimos. [...] Mas os juízes da nação são apenas, co mo dissemos, a boca que pronuncia as palavras da lei; são seres inanimados que não podem moderar sua força, nem seu rigor. (2005, p.170-175)
\end{abstract}

Segundo esta concepção que se instaura a partir da Escola da Exegese, legalista ao extremo, aos juízes compete unicamente a aplicação do direito produzido - expressão da vontade do povo tal como manifestada nas deliberações do poder legislativo -, esvaziandose desta função, portanto, qualquer poder de fonte do direito na produção da norma.

Nesse sentido o discurso de Jean-Paul Marat à Assembléia Geral Francesa em agosto de 1789:

\begin{abstract}
As leis são o caminho do direito, da inocência e da liberdade dos cidadãos: contudo, as mais sábias leis seriam vãs, se pudessem ser contornadas, interpretadas a dizer o que não dizem, se o acusado ou o demandado tivessem que temer pela ignorância, pela parcialidade ou pela corrupção dos juízes. É importante então que as leis sejam justas, claras e precisas; que sejam tomadas sempre ao pé da letra [sic]; que os juízes sejam sensatos e íntegros, e que a instrução do processo seja público. (apud FAURÉ. 1995, p. 290, tradução livre)
\end{abstract}

Necessário destacar, por fim, agora tendo como paradigma o direito anglo-saxão, as bases do estado federal implementado a partir da Constituição estadunidense de 1789, cujas bases, embora tendo como referências a obra de Montesquieu, ultrapassarão, de certo modo, aquilo que este autor havia delineado.

De fato, se princípio da separação de poderes recebe na França os elementos necessários à consolidação do Estado moderno e a superação do Antigo Regime, o paradigma norte-americano terá como primordial finalidade estabelecer o elo necessário ao fortalecimento das 13 (treze) colônias recém-independentes do governo britânico, e, por via oblíqua, organizar o próprio pacto federativo adotado a partir da Constituição americana de 1789, cujo debate, diante de sua especificidade, será analisado no próximo tópico. 


\section{DA SEPARAÇÃO DOS PODERES EM “O FEDERALISTAS” DE HAMILTON, MADISON E JAY.}

Vistas as questões referentes à separação de poderes em John Locke e Montesquieu, matrizes de fundamental importância para o pensamento político contemporâneo, passemos a analisar a adaptação realizada por Hamilton, Madison e Jay no livro "O federalista", cujas bases marcarão o tema sob a ótica do direito estadunidense.

Antes, entretanto, cumpre-nos destacar que "O federalista" é um conjunto de 85 artigos escritos por Alexander Hamilton, John Jay e James Madison publicados anonimamente sob o pseudônimo Publius entre 1787 e 1788, e que tinha como intuito convencer a população de Nova Iorque a ratificar a Constituição estadunidense redigida na Convenção da Filadélfia, em especial a proposta do novo sistema que daí surgia: o federalismo.

Importante observar, nesse giro, a inegável influência que Montesquieu causou nas ideias de Hamilton, Madison e Jay quanto a separação dos Poderes, assimilado e denominado de checks and balances - freios e contrapesos - pelos federalistas enquanto interação entre os Poderes com o propósito de evitar que qualquer deles preponderasse.Partiam também Hamilton, Madison e Jay, de acordo com o pensamento de Montesquieu, do fato de que haveria uma natural tendência de abuso por parte daquele que exerce o poder. Nesse sentido, esclarece MADISON no escrito $\mathrm{n}^{\circ} 48$ :

\footnotetext{
Foi assinalado no artigo anterior que o aforismo político então analisado não exige que os ramos legislativo, executivo e judiciário sejam totalmente desconectados uns dos outros. Tentarei mostrar a seguir que, salvo se esses ramos forem de tal modo entrelaçados para que cada um possa exercer um controle constitucional sobre os outros, o grau de separação que aquele aforismo requer, como essencial a um governo livre, jamais poderá ser devidamente mantido na prática. (...) Não se nega que o poder é, por natureza usurpador, e que precisa ser eficazmente contido, a fim de que não ultrapasse os limites que lhe foram fixados. (2010. p. 315)
}

Por outro lado essa perspectiva acaba afastando-se da visão de Montesquieu na medida em que as instituições que compunham a teoria do "governo misto" por ele propugnada não encontravam instituições correspondentes no modelo norte-americano. E mais, no escólio de Christian Lynch, a própria diversidade de concepção de soberania e de povo já apontava para uma incompatibilidade entre tais modelos.

De fato, diferentemente da visão francesa em que a soberania política circunscreviase preponderância à ordem legislativa - e que justifica a predominância política do Poder Legislativo sobre os demais poderes -, a divisão política estadunidense pendia para um conceito muito mais amplo, abrangendo não só o exercício pelo Congresso norte- 
americano, mas também do chefe do Poder Executivo e dos integrantes do Poder Judiciário, o que acabou por importar, como consequência, na própria consolidação deste peculiar positivismo jurídico em solo estadunidense no ínicio do século XIX.

No escólio de Christian Lynch:

\begin{abstract}
A concepção francesa hegemônica de Estado de direito consagrava a soberania do povo como princípio ordenador da ordem política. A lei era aí vista como um instrumento de uma vontade eticamente definida e, como tal, poderia ser suspensa ao seu arbítrio. Ou seja, era a política que formatava o direito, e não o contrário. [...] No entanto, o juscontratualismo anglo-americano considerava a soberania popular de modo completamente diverso. Para eles, Estado e representação eram elementos apartados do povo e soberania. Se estes últimos davam-lhes origem por meio das eleições, nem por isso estes adquiriam qualquer força autônoma. Os federalistas entendiam que era da "natureza do poder soberano uma avidez (...) que dispõe os que estão investidos de seu exercício a ver com maus olhos todas as tentativas de limitar (...) suas ações" (MADISON, HAMILTON \& JAY, 1993:163). Assim, ao invés de concentrar o poder soberano do povo nas mãos de um único representante, como preconizavam os republicanos franceses, os fundadores da república norte-americana preferiram desinstitucionalizar completamente o locus da soberania, deixando-o nas mãos do povo. (2010, p.110)
\end{abstract}

Nesse passo, a partir das ideias de Montesquieu e da teoria da separação de poderes, obliquamente aplicadas ao positivismo jurídico anglo-saxão e a preocupação de se buscar mecanismos para limitar os abusos que eventualmente adviriam do Poder Legislativo, consolida-se, em nossa visão, este novo paradigma da separação dos poderes que influenciaria, de forma inequívoca, o pensamento político ocidental.

Interessante observar, nessa perspectiva, que ao contrário do modelo francês em que as questões políticas ditavam os rumos do direito e das normas jurídicas - demonstrada no tópico anterior pela subserviência do poder judiciário diante dos demais poderes -, a visão de Hamilton, Madison e Jay se colocava em sentido contrário a esta perspectiva, na medida em que eram as usurpações legislativas, em uma república representativa, a maior ameaça à liberdade do povo.

Interessante observar, nesse passo, que enquanto o poder executivo seria exercido por uma pessoa, o presidente da república, o poder judiciário seria composto por juízes vitalícios e pela suprema corte, ambos os poderes, na visão de Hamilton, Madison e Jay, absolutamente limitados.

Revela-se evidente, dessa forma, a grande a preocupação de tais autores com a função legislativa, na medida em que poderia este poder perseguir suas próprias ambições sem qualquer limite dos outros dois. Nesse sentido esclarece MADISON: 
Onde o Legislativo é exercido por uma assembleia, credenciada por uma suposta influência sobre o povo e com uma absoluta confiança em seu poderio; sendo suficientemente numerosa para perceber as tendências que atuam sobre a massa, mas não tanto que se torne incapaz de perseguir os objetivos de suas ambições, utilizando os meios prescritos pela razão - é contra os abusos deste legislativo que o povo deve orientar suas suspeitas e concentrar todas as suas precauções. (2010. p. 316)

Surge diante de tal perspectiva a divisão bipartida do poder legislativo apresentada por Montesquieu, não como meio de contemplar os diferentes grupos sociais integrantes da sociedade na esteira da tese polibiana, mas, ao contrário, visando resguardar os demais poderes já que o legislativo naturalmente seria constitucionalmente mais abrangente e menos suscetível de uma limitação. Argumenta MADISON a esse respeito:

Será suficiente assinalar com precisão, ao constituir-se o governo, os limites dos três
ramos e confiar nessas barreiras de papel impresso como capazes de deter o espírito
usurpador do poder? Esta é a segurança que parece ter sido a principal imaginada
pelos elaboradores da maioria das Constituições americana. Todavia, a experiência
ensina-nos que a eficácia da provisão tem sido gradativamente superestimada e que é
indispensável alguma defesa suplementar, protegendo os ramos mais fracos do
governo contra os mais fortes. O Legislativo está, por toda a parte, estendendo a esfera
de suas atividades e abarcando todo o poder com seus ambiciosos tentáculos. (2010.
p. 110)

A solução para o equilíbrio das funções políticas, dentro dessa visão inicial, poderia residir no senado federal, na medida em que dele poderia se esperar a função de regulador estrutural do sistema constitucional. Ocorre, entretanto, que esta concepção do senado como poder moderador colapsou não só pelo caráter oligárquico e elitista de sua atuação nos primeiros momentos de independência estadunidense, como também em razão de sua natural sujeição às pressões político-partidárias.

Nesse contexto surge o relevante papel do Poder Judiciário para a democracia norteamericana, na medida em que, em detrimento da representação do Poder Legislativo, fundamentava sua atuação na concepção criada pelo povo enquanto detentor real e efetivo da soberania estatal, e, por isso mesmo, materializada por intermédio da Constituição.

Negar tal evidência, diz Hamilton (2010), corresponde a afirmar que o representante é superior ao representado, que os delegados do povo estão acima dele próprio, que aqueles que agem em razão de delegações de poderes estão impossibilitados de fazer não apenas o que tais poderes não autorizam, mas, sobretudo, o que eles proíbem.

Dessa forma a Constituição surge enquanto o cerne da organização estadunidense, instrumento normativo não só apto a equacionar a nova realidade decorrente da centralização das 13 (treze) colônias e o estado federal, mas também por ser o balizador desta nova acepção da separação dos poderes trazida a partir da consolidação do "povo" enquanto titular soberano do exercício do poder estatal. 
Nesse sentido, apontando a relevância da Constituição para o sistema norteamericano político, conclui Madison:

Todavia, esta conclusão não deve significar uma superioridade do Judiciário sobre o Legislativo. Somente supõe que o poder do povo é superior a ambos; e que, sempre com vontade do Legislativo, traduzida em suas leis, se opuser à do povo, declarada na Constituição, os juízes devem obedecer a esta, não àquela, pautando suas decisões pela lei básica, não pelas leis ordinárias. (2010, p. 480)

Assim, na medida em que a organização político-administrativa estadunidense se consolidava, ao Poder Judiciário era lícito lançar mão dos termos da Constituição instaurada, ainda que de forma discreta e neutra, para invalidar atos dos demais poderes políticos.

E foi exatamente esta concepção e paradigma da Constituição que preponderou no contexto do início do século passado, inclusive no Brasil, tendo sido determinante para a superação da dogmática exegética no pensamento político constitucional pátrio.

O que se observa, desse modo, é que vinculado à defesa dos dogmas do federalismo enquanto forma de estado, este movimento constitui, de forma inequívoca, o embrião da atuação independente da função jurisdicional, ainda que nesse primeiro momento de fundo conservador, na medida em que, alçando o Poder Judiciário à suprema função de guardião da Constituição, concede-lhe a relevante atribuição para efetivar os atos necessários a defesa de seus ideais.

Em síntese, e valendo-se do admirável simbolismo dos autores de "O Federalista", as funções estatais se consubstanciariam no seguinte esquema:

\footnotetext{
Quem analisar atentamente os diferentes ramos do poder percebe desde logo que, em governo em que eles são separados uns dos outros, o Judiciário, pela própria natureza de suas funções, será sempre o menos perigoso para os direitos políticos previstos na Constituição, pois será o de menor capacidade para ofendê-los ou violá-los. O Executivo dispõe não apenas das honrarias, mas também da espada. O Legislativo, além de manter os cordões da bolsa, prescreve as normas pelas quais cada cidadão deve regular seus direitos e deveres. O Judiciário, porém, não tem a menor influência sobre a espada nem sobre a bolsa; não participa da força nem da riqueza da sociedade e não toma resoluções de qualquer natureza. (2010. p. 478)
}

Foi nesse sistema, em que cada um dos três poderes tinha a recíproca possibilidade de intervir nos demais a fim de evitar a concentração e a usurpação nas mãos de um só, que se constituiu e desenvolveu uma nova acepção da teoria da separação dos poderes norte-americana - a teoria dos freios e contrapesos -, instrumento fundamental para a democracia representativa 
instaurada e, por via de consequência, para o próprio desenvolvimento de inúmeras teoria de direitos nos últimos séculos.

\section{CONSIDERAÇÕES FINAIS:}

De tudo o que foi exposto, o que se observa, de fato, é que extrapolando o mero limite das questões legais, os movimentos políticos da organização dos poderes estatais da tradição jurídica ocidental surgem como paradigmas para a construção e consolidação da sociedade tal qual nós atualmente o conhecemos.

Pretendeu o presente artigo discutir as matrizes fundamentais do princípio da separação dos poderes, em especial na perspectiva da função judiciária.

Desde John Locke e seu célebre "Segundo Tratado sobre o Governo" vimos que a concentração de todos os poderes em uma só pessoa ou um só grupo acarreta na inequívoca usurpação por parte de seu titular.

Nestes termos, sugere o pai do liberalismo a necessidade da bipartição dos poderes internos do estado, a fim de que ambos se limitem mutuamente. A função judiciária, nesse espectro, estaria incluída na tarefa executiva, que englobaria tanto o que a executiva propriamente dita, como a função jurisdicional.

Vimos, ainda, que a preocupação de usurpação do poder apresentada por Locke ecoa significativamente em Montesquieu, de modo que mereceu por parte deste uma teorização muito mais completa e elaborada, resultando exatamente na elaboração da clássica teoria da tripartição de poderes.

Outrossim, constatamos que a "divisão horizontal" de poder defendida por Montesquieu, consubstanciada no clássico conceito de governo misto de Políbio foi a grande proposta apresentada no livro "O espírito das leis", principalmente em razão do nulo e invisível exercício da função jurisdicional na visão do referido autor, de modo que a "equivalência" tão difundida na teoria da separação dos poderes visava, na realidade, menos uma independência e harmonia tão comumente difundidas, mas propiciar a existência de instâncias independentes que assegurassem que não houvesse o abuso por quaisquer deles.

Relevante destacar, por outro lado, que a partir destes dogmas apresentados no "Espírito das leis" não foi possível constituir plenamente o desenvolvimento que as bases estatais estadunidenses demandavam em seu período inicial de organização, tanto que, conforme visto em tópico específico acima, a adaptação das ideias de Montesquieu por Hamilton, Madison e Jay iria acrescentar ingredientes fundamentais e necessários para a estabilização deste novo Estado que surgia. 
De fato, é possível observar em "O federalista" que ao contrário do modelo francês em que as questões políticas ditavam os rumos do direito e das normas jurídicas, a visão de estadunidense se colocou no sentido de que eram as usurpações legislativas, na república representativa, a maior ameaça à liberdade do povo.

E mais, eram necessários critérios de freios e contrapesos (checks and balances) possibilitando que cada um dos três poderes interviesse nos demais a fim de evitar a concentração e a usurpação nas mãos de um só.

Esta visão, adaptada à democracia representativa, se constituiu a maior contribuição norte-americana para a teoria da separação dos poderes que seria utilizada por diversos outros países posteriormente, inclusive o Brasil.

De fato, por tudo que foi debatido no presente artigo, conclui-se que foi a natural tendência de usurpação do poder por aquele que o detém o principal combustível para o aperfeiçoamento da teoria da separação dos poderes.

Se por um lado John Locke apresentou o germe da discussão ao buscar uma saída para evitar o retorno do absolutismo dos Stuarts; Montesquieu a teorização muito mais completa e elaborada resultando na clássica teoria da tripartição de poderes; e Hamilton, Madison e Jay a instituição dos freios e contrapesos que equilibrassem a democracia representativa americana; foi o conjunto deste estudo (e muitos outros, a partir destes) que, por outro, propiciou a consolidação desta relevante teoria como princípio fundamental do constitucionalismo moderno 


\section{BIBLIOGRAFIA}

ALBUQUERQUE, J. A. Guilhon. Os clássicos da política. Org. WEFFORT, Francisco C. 14. ed. São Paulo: Ática, 2006.

BOBBIO, Norberto. A teoria das formas de governo. Trad. de Sérgio Bath, Brasília: Editora Universidade de Brasília, 1997.

CHEVALLIER, Jean-Jacques. As grandes obras políticas de Maquiavel a nossos dias. Rio de Janeiro: Agir, 1999.

DUGUIT, Léon, La separación de poderes y La asamblea nacional de 1789. Trad. de Pablo

Pérez Tremp, Madrid, Centro de Estudios Constitucionales, 1996.

FARIAS NETO, Pedro Sabino de, Ciência política: enfoque integral avançado. São Paulo: Atrlas, 2011.

FAURÉ, Christine, Las declaraciones de los derechos del hombre de 1789, México: Fondo de Cultura Económica, 1995.

HAMILTON, Alexander; MADISON, James; JAY, Jonh. "O federalista". trad. de Ricardo Rodrigues Gama, 2a ed. Campinas: Russell Editores, 2010.

LYNCH, Christian Edward Cyril. Do direito à política: a gênese da jurisdição constitucional norte-americana. In Revista Ciências Sociais / Universidade Gama Filho. - Vol. 16, Rio de Janeiro: Editora Gama Filho, 1995.

LOCKE, Jonh. Segundo tratado sobre o governo. São Paulo: Martin Claret, 2010.

MARINONI, Luiz Guilherme. Aproximação crítica entre as jurisdições de civil law e de common law e a necessidade de respeito aos precedentes no Brasil. Curitiba: Revista da Faculdade de Direito - UFPR, 2009. n. 49, p. 11-58.

MONTESQUIEU, Charles de Secondat, Baron de. O espírito das leis. $3^{\mathrm{a}}$ ed. São Paulo: Martins Fontes, 2005.

SALDANHA, Nelson. "Teoria do Direito e Crítica Histórica” Rio de Janeiro: Freitas Bastos, 1987.SARMENTO, Daniel. Por um constitucionalismo inclusivo: história constitucional brasileira, teoria da constituição e direitos fundamentais. Rio de Janeiro: Lumem Juris,

2010 . 